\title{
Secondary Sex Ratio in Eurasian Eagle-Owls: Early-breeding Females Produce More Daughters
}

Author(s): Olga Mora, Maria del Mar Delgado, and Vincenzo Penteriani

Source: Journal of Raptor Research, 44(1):62-65. 2010.

Published By: The Raptor Research Foundation

DOI: http://dx.doi.org/10.3356/JRR-09-08.1

URL: http://www.bioone.org/doi/full/10.3356/JRR-09-08.1

BioOne (www.bioone.org) is a nonprofit, online aggregation of core research in the biological, ecological, and environmental sciences. BioOne provides a sustainable online platform for over 170 journals and books published by nonprofit societies, associations, museums, institutions, and presses.

Your use of this PDF, the BioOne Web site, and all posted and associated content indicates your acceptance of BioOne's Terms of Use, available at www.bioone.org/ page/terms_of_use.

Usage of BioOne content is strictly limited to personal, educational, and noncommercial use. Commercial inquiries or rights and permissions requests should be directed to the individual publisher as copyright holder. 


\title{
Short Communications
}

J. Raptor Res. 44(1):62-65

(C) 2010 The Raptor Research Foundation, Inc.

\section{Secondary Sex Ratio in Eurasian Eagle-Owls: Early-breeding Females Produce MORE DAUGHTERS}

\author{
Olga Mora ${ }^{1}$ AND Maria del Mar Delgado \\ Department of Conservation Biology, Estación Biológica de Doñana, Consejo Superior de Investigaciones Científicas, c/ Americo \\ Vespucio s/n, 41092 Sevilla, Spain \\ Vincenzo Penteriani ${ }^{2}$ \\ Department of Conservation Biology, Estación Biológica de Doñana, Consejo Superior de Investigaciones Científicas, c/ Americo \\ Vespucio s/n, 41092 Sevilla, Spain
}

and

Finnish Museum of Natural History, Zoological Museum, University of Helsinki, FI-00014 Helsinki, Finland

KEY WORDS: Eurasian Eagle-Owl; Bubo bubo; offspring sex ratio; sexual dimorphism; sex ratio.

Knowledge of sex ratios in bird populations is a key aspect of species' life histories. Sex allocation is subject to multiple influences (Hardy 2002), females being able to adjust the offspring sex ratio according to diverse social, parental, and environmental conditions (Bensch 1999). According to the theory of sex-ratio allocation (Fisher 1958), parents should allocate an equal amount of resources to each sex because half of all genes are passed on through the male and half through the female. This means that because exactly half the parental effort (e.g., food) provided to offspring should go to males and females, the sex with the greatest nutritional needs should be produced in lower relative numbers.

In most raptor offspring, females are larger than males, and the former often outnumber males, at least partly, because of their supposed superiority in competition for food in the nest (Lack 1954, Yom-Tov and Ollason 1976). When individuals of one sex are more costly than the other to produce and/or to raise successfully (e.g., Bednarz and Hayden 1991, Appleby et al. 1997, Krijgsveld et al. 1998), as in dimorphic species, sex ratios may differ from equality. For example, a resource shortage may make it impossible for parents to supply the nestlings with the optimal amount of food, where optimal amount is defined by the relationship between nestling size and reproductive success (Smith and Fretwell 1974).

\footnotetext{
${ }^{1}$ Email address: olgamora@hotmail.com

2 Email address: penteriani@ebd.csic.es
}

Information on the sex ratio of owls is scarce (Mikkola 1983, Blanco et al. 2002, Duncan 2003) and sometimes contradictory. For example, female Common Scops-Owls (Otus scops) seem to control the production of daughters and sons in relation to laying order (Blanco et al. 2002), but Hörnfeldt et al. (2000) showed no relationship between hatching order and offspring sex ratio in Boreal (Tengmalm's) Owl (Aegolius funereus). In addition, physical condition of parents seems to affect offspring sex ratio in Tawny Owls (Strix aluco), female-biased clutches being more frequent in those territories with more abundant prey (Appleby et al. 1997). Female Ural Owls (Strix uralensis) produce more males in poor food conditions (Brommer et al. 2003). Finally, Hipkiss et al. (2002) and Hipkiss and Hörnfeldt (2004) observed high interannual variation in the hatching sex ratio of Boreal Owl and a significant correlation between favorable food supply and a femalebiased sex ratio. Such differences in the offspring sex ratio may be due to the different characteristics of life-histories of different species, as well as the role that local factors may play in sex allocation of the young (Desfor et al. 2007). For this reason, studies on characteristics and potential factors determining the sex ratio of owl populations are needed.

To our knowledge, no information exists on sex ratio of Eurasian Eagle-Owl (Bubo bubo) populations. Eagle-owls, the largest owls in Europe (1.5-4 kg) exhibit reverse sexual dimorphism and hatching asynchrony (Mikkola 1983). Thus, they may have a mechanism for sex allocation (Olsen and Cockburn 1991), as females may be able to manipulate the sex of their nestlings depending on the environmental conditions. We studied the secondary sex ratio of the offspring (i.e., estimated after embryo mortal- 
ity and/or after some nestlings have died during the first days after hatching; hereafter "sex ratio") in an eagle-owl population in southern Spain. We predicted that during the later breeding attempts of the year or within low-quality breeding sites (i.e., under less favorable food conditions), females should more frequently produce males, the less costly sex (Velando 2002, Velando et al. 2002, Sasvári and Nishiumi 2005).

\section{Methods}

Our study was conducted during the 2003-07 breeding seasons within the Sierra Norte of Seville (Sierra Morena massif, southwestern Spain), a hilly area ranging between 60 and $200 \mathrm{~m}$ asl (see Penteriani et al. 2005a). This area is characterized by patches of abundant European rabbits (Oryctolagus cuniculus), the main prey of the eagle-owl in Mediterranean habitats (Delibes and Hiraldo 1981). Breeding densities of eagle-owls are extremely high, reaching about 40 breeding territories per $100 \mathrm{~km}^{2}$. In this region, egg-laying may start as early as mid-December, and clutch size can vary from 1 to 5 eggs, with both these extremes being quite rare.

Measurement of Reproductive Data. Nests were found using a combination of direct and indirect methods (see Penteriani et al. 2004 for more details), including: (1) passive auditory surveys at sunrise and sunset, when the vocal activity of adults was most intense; (2) passive auditory surveys of calling young during the entire night, from when nestlings were ca. $40 \mathrm{~d}$ old until the end of July (when juveniles begin dispersal in our study area); and (3) searches of rocky areas to detect nests, pellets, and feeding perches. The majority of nests were on the ground or on very accessible cliffs, which allowed for easy recording of reproductive data with minimal disturbance.

Because of the risk that females abandon their eggs or small nestlings when disturbed (V. Penteriani and M. Delgado unpubl. data) and because very young nestlings cannot thermoregulate, we avoided checking the nests early in the breeding season. As a trade-off between the risk of nest desertion and the possibility that biases in determining the hatching order may result from sexual size dimorphism if nests are only observed when owlets are 30-40 d old, we generally examined the broods during the first two weeks after hatching, when the effect of hatching asynchrony predominates over that of sexual dimorphism (see also Penteriani et al. 2005a).

We collected blood samples $(2 \mathrm{~mL}$ ) from the brachial vein when nestlings were ca. 30-35 d old. Blood samples were stored in tubes with heparin at $4^{\circ} \mathrm{C}$ until arrival at the laboratory, where they were centrifuged for $10 \mathrm{~min}$ at $4000 \mathrm{rpm}$; plasma was separated and stored at $-78^{\circ} \mathrm{C}$.

Egg-laying date was estimated indirectly by using the age of nestlings, following Penteriani et al. (2005a).

Sex Ratio of Nestlings. We sexed the nestlings by molecular procedures using DNA extracted from the blood (Griffiths et al. 1998). We calculated the average sex ratio of 101 nestlings ( $n=45$ broods) belonging to 22 distinct nests/territories. Sex ratio was defined as the number of males divided by the total number of individuals (i.e., males/[males + females $]$ ).

Capture of Adult Owls. We captured breeding males ( $n=10$ ) by simulating a territorial intrusion using a taxidermic mount and a playback of a male call. A net behind the mount caught responding individuals. Females $(n=3)$ were trapped with a bownet (Northwoods Limited, Inc., Rainier, Washington) placed in the nest when nestlings were $20-35$ d old. Nestlings were put in a box with a metal grid making them visible to their parents, who were caught when they returned to the nest. After each bownet trapping session (which lasted from sunset to sunrise), we fed nestlings and released them in the nest. We measured body mass (to the nearest $10 \mathrm{~g}$, with $1 \mathrm{~kg}$ Pesola scales) and tarsus length (using a digital caliper, $\pm 0.1 \mathrm{~mm}$ ).

We used the adult blood samples $(2 \mathrm{~mL}$, taken from the brachial vein) to measure parent owls' biochemical parameters (i.e., hematocrit values, cholesterol, triglycerides and free glycerol, uric acid, urea, and total proteins concentrations), and four immune measures of stress and health (i.e., total leukocyte count, proportion of the different types of white blood cells, heterophiles: lymphocytes ratio, and intensity of two species of Haematozoa parasite).

Determination of Adult Diet. Following Penteriani et al. (2005b), we evaluated the percentage biomass of rabbit by repeated nest visits to collect prey remains and pellets and by direct observations at sunset and sunrise. Prey remains and pellets were identified by macroscopic comparison with reference collections. We estimated live biomass by using direct measurements, mass data from the study area, and bibliographic sources (Lourenço 2006).

Rabbit Surveys. We estimated a yearly index of rabbit abundance using line transects, an effective method to compare the densities of abundant species among different zones and/or periods (Fitzner et al. 1977, Telleria 1986). Two censuses per year (in December and April, when rabbit density is the lowest and the highest, respectively) were done along a same line transect of $25 \mathrm{~km}$ crossing the study area. The census, performed by car (driving speed $=20 \mathrm{~km} / \mathrm{hr}$ ) and by the same observer, started one hour before sunset, a peak time for rabbit activity (Villafuerte et al. 1993).

Statistical Analysis. We tested whether: (1) the observed sex ratio differed significantly from the null expectation (proportion of males $=0.5$ ), using the binomial test (Hardy 2002), and (2) the sex ratio fitted a binomial distribution (i.e., the distribution predicted by evolutionary theory; see Hardy 2002 for more details). Statistically significant results of one or both of these tests could be indicative of nonrandom variation in the sex-ratio distribution.

Secondly, and following Krackow and Tkadlec (2001), we used a GLMM to test whether the sex ratio (as dependent variable) of the study population was correlated to: (1) the egg-laying date; (2) year; (3) clutch size; (4) hatching order; (5) the quality of the breeding site, as measured by two parameters (the amount of rabbit in the parent 
owls' diet and the yearly index of rabbit abundance); and (6) several parameters of parents' quality. Morphological parameters were summarized into a biometrical index (Body Condition Index) estimated by a reduced major axis (RMA) regression (Green 2001), using logarithm of both body mass and tarsus length. Additional measures of biochemical parameters, immune responses, and parasite loads (see above) were also included as variables.

The statistical analyses were performed with SAS procedure GLIMMIX. Our dependent variable showed a binomial distribution, and hence it was modeled using binomial distribution and the default logit-link function. We considered nest and year as random effects. The model was built through a forward stepwise procedure in which the least significant terms or interactions were sequentially added until we obtained a minimal adequate model that retained only effects significant at the $5 \%$ probability level (Crawley 1993). All statistical analyses were performed with SAS and SPSS software.

\section{Results AND Discussion}

The population we studied exhibited a nestling sex ratio of 0.53 ( $P=0.6$; binomial tests), which differed significantly from the binomial distribution $\left(\chi^{2}{ }_{100}=116.1 ; P<\right.$ $0.003)$, suggesting a possible parental control of sex allocation.

The GLMM analysis indicated that the sex-ratio of this Eurasian Eagle-Owl population was influenced only by the egg-laying date $(\mathrm{F}=9.27, P<0.05$; all other parameters $P>0.1)$. That is, when an earlier laying occurred, a greater number of female nestlings were raised to ca. $35 \mathrm{~d}$ old. Moreover, when laying occurred later in the year, a greater number of male nestlings were raised. A relationship between laying date and the offspring sex-ratio has been found in other bird species. For example, Andersson et al. (2003) showed that laying date and offspring sex ratio were highly correlated in Common Sandpipers (Actitis hypoleucos). Similarly, laying date and laying sequence also influenced the sex ratio of Crimson Rosella (Platycercus elegans; Krebs et al. 2002), and the bias in offspring sex ratio in Little Grassbirds (Megalurus gramineus) was also highly correlated with the laying date (McIntosh et al. 2003).

Females may adjust the sex ratio of their clutch according to their ability to withstand the costs of reproduction. Under conditions of high food availability, females' physical conditions are improved and, therefore, they may start breeding earlier and be more able to obtain the necessary prey to raise female nestlings. This conforms with the Trivers and Willard's hypothesis (1973), which holds that vertebrates may vary the sex ratio of their offspring in response to the mother's physical condition (but see Krackow 2002). Other owl species, like the Ural Owl and the Boreal Owl, lay their eggs earlier in the year and produce a greater number of female than male nestlings when food availability is high (Brommer et al. 2003, Hipkiss and Hörnfeldt 2004). However, we cannot dismiss the possibil- ity that later pairs produce a higher proportion of the less costly sex because food availability will predictably decrease as breeding season advances, this being particularly critical for late breeders (i.e., eagle-owls may adjust sexratio according to food availability during the nestlingrearing period rather than in relation to their own condition).

Finally, because we did not collect information on offspring mortality prior to DNA sampling, the increasing number of males in late broods might also be due to differential mortality at the beginning of the nestling phase (i.e., relatively more females dying in late broods).

\section{COCIENTE SECUNDARIO DE SEXO EN BUBO BUBO: HEMBRAS QUE SE REPRODUCEN MÁS TEMPRANO PRODUCEN MÁS HIJAS}

RESUMEN.-El búho Bubo bubo es un depredador nocturno con ligero dimorfismo sexual invertido. Con el fin de determinar el cociente de sexos de la descendencia, analizamos muestras de sangre de 101 pollos correspondientes a 45 puestas, de 22 nidos pertenecientes a la población de $B$. bubo de la Sierra Norte de Sevilla (sur de España; 2003-07). Aunque el cociente de sexos de nuestra población durante todos estos años fue 1:1, las parejas que comenzaron a criar antes produjeron más hembras. Admitiendo que los pollos que son hembras son más grandes y que son el sexo más costoso, podemos suponer que estas parejas producen más hembras debido a la alta disponibilidad de recursos tróficos durante las crías más tempranas.

[Traducción del equipo editorial]

\section{ACKNOWLEDGMENTS}

We are grateful to $\mathrm{P}$. Sunde for his useful comments, as well as to G. Bortolotti, J. Figuerola, X. Cerdá, L. López, J.E. Martínez, G. Rivera, and two anonymous referees for their remarks on an earlier version of the manuscript.

\section{Literature Cited}

Andersson, M., J.G.L. Wallander, E. Akst, J.M. Reed, AND R.C. FleisCHER. 2003. Adaptive seasonal trend in brood sex ratio: test in two sister species with contrasting breeding systems. J. Evol. Biol. 16:510-515.

Appleby, B.M., S.J. Petty, J.F. Blakey, P. Rainey, And D.W. MaCDOnALD. 1997. Does variation of sex ratio enhance the reproductive success of offspring in Tawny Owls (Strix aluco)? Proc. R. Soc. Lond. B. 264:1111-1116.

Bednarz, J.C. And T.J. Hayden. 1991. Skewed brood sex ratio and sex-biased hatching sequence in Harris's Hawks. Am. Nat. 137:116-132.

BENSCH, S. 1999. Sex allocation in relation to parental quality. Pages 451-466 in N.J. Adams and R.H. Slotow [EDS.], Proceedings of the 22nd International Ornithological Congress. Durban BirdLife, Johannesburg, South Africa.

Blanco, G., J.A. DÁvila, J.A. López SePtiem, R. Rodríguez, AND F. MARTínEz. 2002. Sex biased initial eggs favours sons in the slightly size-dimorphic Scops Owl (Otus scops). Biol. J. Linn. Soc. 76:1-7. 
Brommer, J.E., P. Farell, T. Pihlaja, J.N. Painter, C.R. Primmer, AND H. PietiäInen. 2003. Ural Owl sex allocation and parental investment under poor food conditions. Oecología 137:140-147.

Crawley, M.J. 1993. GLIM for ecologists. Blackwell Scientific Publications, Oxford, U.K.

Delibes, M. AND F. HiRaldo. 1981. The rabbit as prey in the Iberian Mediterranean ecosystem. Pages 614-622 in K. Myers and C.D. MacInnes [EDs.], Proceedings of the World Lagomorph Conference. Guelph University Press, Guelph, Ontario Canada.

Desfor, K.B., J.J. Boomsma, And P. Sunde. 2007. Tawny owls Strix aluco with reliable food supply produce male-biased broods. Ibis 149:98-105.

DunCAN, J.R. 2003. Owls of the world: their lives, behavior and survival. Firefly Books, Buffalo, NY U.S.A.

Fisher, R.A. 1958. The genetical theory of natural selection. Dover, New York, NY U.S.A.

Fitzner, R.E., L.E. Roger, AND D.W. UREsK. 1977. Techniques useful for determining raptor prey species abundance. J. Raptor Res. 11:67-71.

Green, A. 2001. Mass/length residuals: measures of body condition or generators of spurious results? Ecology 82:1473-1483.

Griffiths, R., M.C. Double, K. OrR, and R.J.G. Dawson. 1998. A DNA test to sex most birds. Mol. Ecol. 7:1071-1075.

HaRdy, I.C.W. 2002. Sex ratios concepts and research methods. Cambridge University Press, Cambridge, U.K.

Hipkiss, T., B. Hörnfeldt, U. Eklund, ANd S. BERlin. 2002. Year-dependent sex-biased mortality in supplementaryfed Tengmalm's Owl nestlings. J. Anim. Ecol. 71:693699.

AND —. 2004. High interannual variation in the hatching sex ratio of Tengmalm's Owl broods during a vole cycle. Popul. Ecology 46:263-268.

Hörnfeldt, B., T. Hipkiss, A.K. Fridolfsson, U. EkLund, AND H. Ellegren. 2000. Sex ratio and fledging success of supplementary-fed Tengmalm's Owl broods. Mol. Ecol. 9:187-192.

KRACKOW, S. 2002. Why parental sex ratio manipulation is rare in higher vertebrates. Ethology 108:1041-1056.

- AND E. TKADLEC. 2001. Analysis of brood sex ratios: implications of offspring clustering. Behav. Ecol. Sociobiol. 50:293-301.

Krebs, E.A., D.J. Green, M.C. Double, And R. Griffiths. 2002. Laying date and laying sequence influence the sex ratio of Crimson Rosella broods. Behav. Ecol. Sociobiol. 51:447-454.

Krijgsveld, K.L., C. Dijkstra, G.H. Visser, and S. DaAn. 1998. Energy requirements for growth in relation to sexual size dimorphism in Marsh Harrier Circus aeruginosus nestlings. Physiol. Zool. 71:693-702.
LACK, D. 1954. The natural regulation of animal numbers. Clarendon, Oxford, U.K.

Lourenç, R. 2006. The food habits of Eurasian EagleOwls in southern Portugal. J. Raptor Res. 40:297-300.

McIntosh, R.R., R. Kats, M. Berg, J. Komdeur, And M.A. ELGAR. 2003. Breeding ecology and bias in offspring sex ratio in Little Grassbirds (Megalurus gramineus). Aust. J. Zool. 51:505-514.

Mikkola, H. 1983. Owls of Europe. T. and A.D. Poyser, Calton, U.K.

Olsen, P. AND A. CockBurn. 1991. Female-biased sex allocation in Peregrine Falcons and other raptors. Behav. Ecol. Sociobiol. 28:417-423.

Penteriani, V., M.M. Delgado, M. Gallardo, and M. FERRER. 2004. Spatial heterogeneity and structure of bird populations: a case example with the eagle owl. Popul. Ecol. 46:185-192.

- - - - C C. Maggio, A. Aradis, and F. Sergio. 2005a. Development of chicks and pre-dispersal behaviour of young in the eagle owl Bubo bubo. Ibis 147:155-168.

, F. Sergio, M.M. Delgado, M. Gallardo, and M. FERRER. 2005b. Biases in population studies due to sampling in heterogeneous environments: a case study with the eagle owl. J. Field Ornithol. 76:237-244.

SASVÁRI, L. AND I. NiShIUMI. 2005. Environmental conditions affect offspring sex-ratio variation and adult survival in Tawny Owls. Condor 107:324-326.

Smith, C.C. AND D. Fretwell. 1974. The optimal balance between size and number of offspring. Am. Nat. 108:499-506.

Telleria, J.L. 1986. Manual para el censo de los Vertebrados Terrestres. Raices, Madrid, Spain.

TrIVERS, R.L. AND D.F. WILLARD. 1973. Natural selection of parental ability to vary the sex ratio of offspring. Science 179:90-92.

VELANDO, A. 2002. Experimental manipulation of maternal effort produces differential effect on sons and daughters. Implications for adaptive sex ratios in Blue-footed Booby. Behav. Ecol. 13:443-449.

_ J. GRaves, ANd J.E. ORtega-Ruano. 2002. Sex ratio in relation to timing of breeding, and laying sequence in a dimorphic seabird. Ibis 144:9-16.

Villafuerte, R., M.B. Kufner, M. Delibes, and S. Moreno. 1993. Environmental factors influencing the seasonal daily activity of the European rabbit (Oryctolagus cuniculus) in a Mediterranean area. Mammalia 57:341-347.

Yom-Tov, Y. AND G. OlLASON. 1976. Sexual dimorphism and sex ratios in wild birds. Oikos 27:81-85.

Received 16 February 2009; accepted 26 October 2009 